\title{
Effect of ovarian tissue storage in Morus nigra extract on the morphology and DNA fragmentation of ovine preantral follicles
}

\author{
Efeito da conservação de tecido ovariano em extrato de \\ Morus nigra sobre a morfologia e fragmentação de DNA de \\ folículos pré-antrais ovinos
}

\author{
Agnes Yasmin Pitombeira Cavalcante ${ }^{1 *}$; Ricássio de Sousa Barberino ${ }^{2}$; Bruna \\ Bortoloni Gouveia ${ }^{3}$; Maria Éllida de Sousa Bezerra4; Vanúzia Gonçalves Menezes ${ }^{3}$; \\ Grasielly Rocha Souza ${ }^{5}$; Larissa Araújo Rolim; ${ }^{6}$ Pedro José Rolim-Neto ${ }^{7}$; Jackson \\ Roberto Guedes da Silva Almeida ${ }^{8}$; Maria Helena Tavares de Matos ${ }^{9}$
}

\begin{abstract}
This study demonstrated the effect of Morus nigra leaf extract during ovine ovarian tissue transportation on the survival and apoptosis of preantral follicles in vitro. High Performance Liquid Chromatography (HPLC) was used to determine the fingerprint chromatogram of the crude ethanolic extract. Four pairs of ovaries from four sheep were collected. The ovarian cortex was fragmented and one fragment was fixed in $10 \%$ buffered formaldehyde and processed for histological and TUNEL analyses (fresh control). The other fragments were placed in Minimal Essential Medium (MEM - control medium) or M. nigra extract $(0.025 ; 0.05$ or $0.1 \mathrm{mg} / \mathrm{mL})$ and stored (simulating transport) at $4^{\circ} \mathrm{C}$ for 6,12 or 24 h. Preserved fragments $(6 \mathrm{~h})$ were also destined to histological and TUNEL analyses. HPLC analysis confirmed the presence of antioxidant compounds (rutin, isoquercetin e kaempferitrin) in the extract. There was a decrease $(\mathrm{P}<0.05)$ in the percentage of morphologically normal preantral follicles after preservation in all treatments compared to the fresh control. The percentage of normal preantral follicles after preservation in M. nigra at $0.05 \mathrm{mg} / \mathrm{mL}$ for $6 \mathrm{~h}$ was higher $(\mathrm{P}<0.05)$ than in MEM or $0.025 \mathrm{mg} /$ $\mathrm{mL}$ M. nigra and similar $(\mathrm{P}>0.05)$ to $0.1 \mathrm{mg} / \mathrm{mL}$ of the extract. Apoptosis increased $(\mathrm{P}<0.05)$ after conservation for $6 \mathrm{~h}$ in all treatments compared to the fresh control. Moreover, TUNEL positive cells decreased $(\mathrm{P}<0.05)$ after preservation in 0.05 or $0.1 \mathrm{mg} / \mathrm{mL}$ M. nigra compared to MEM or $0.025 \mathrm{mg} /$ $\mathrm{mL}$ M. nigra. In conclusion, $0.05 \mathrm{mg} / \mathrm{mL}$ M. nigra extract can be used as a preservation medium for ovine ovarian tissue at $4^{\circ} \mathrm{C}$ for up to $6 \mathrm{~h}$.
\end{abstract}

Key words: Ovine. Oocyte. Preantral. HPLC. Medicinal Plant.

\footnotetext{
${ }^{1}$ Discente, Curso de Pós-Graduação em Ciências Veterinárias no Semiárido, CPGCVS, Núcleo de Biotecnologia Aplicada ao Desenvolvimento de Folículos Ovarianos, BIOFOV, Universidade Federal do Vale do São Francisco, UNIVASF, Petrolina, PE, Brasil. E-mail: a.yasmin.pc@hotmail.com

2 M.e em Ciências Veterinárias no Semiárido, Núcleo de Biotecnologia Aplicada ao Desenvolvimento de Folículos Ovarianos, BIOFOV, UNIVASF, Petrolina, PE, Brasil. E-mail: cassiobarberino@hotmail.com

${ }^{3}$ Discentes, Rede Nordeste de Biotecnologia, RENORBIO, Núcleo de Biotecnologia Aplicada ao Desenvolvimento de Folículos Ovarianos, BIOFOV, UNIVASF, Petrolina, PE, Brasil. E-mail: bruna.bortoloni@gmail.com; vanuziagm@yahoo.com.br

${ }^{4}$ Discente, Curso de Pós-Graduação em Ciência Animal, CPGCA, Núcleo de Biotecnologia Aplicada ao Desenvolvimento de Folículos Ovarianos, BIOFOV, UNIVASF, Petrolina, PE, Brasil. E-mail: mariaellida@hotmail.com

5 Discente, Programa de Pós-Graduação em Ciências Farmacêuticas, PPGCF, Universidade Federal do Piauí, UFPI, Teresina, PI, Brasil. E-mail: grasyyrocha@hotmail.com

${ }^{6}$ Prof ${ }^{a}$, Central de Análise de Fármacos, Medicamentos e Alimentos, CAFMA, UNIVASF, Petrolina, PE, Brasil. E-mail: larissa. rolim@univasf.edu.br

${ }^{7}$ Prof., Departamento de Ciências Farmacêuticas, Universidade Federal de Pernambuco, UFPE, Recife, PE, Brasil. E-mail: rolim. pedro@gmail.com

8 Prof., Núcleo de Estudos e Pesquisas de Plantas Medicinais da UNIVASF, NEPLAME, UNIVASF, Petrolina, PE, Brasil. E-mail: jackson.guedes@univasf.edu.br

9 Prof ${ }^{a}$, Núcleo de Biotecnologia Aplicada ao Desenvolvimento de Folículos Ovarianos, BIOFOV, UNIVASF, Petrolina, PE, Brasil. E-mail: helena.matos@univasf.edu.br

* Author for correspondence
} 


\title{
Resumo
}

\begin{abstract}
Este estudo demonstrou o efeito do extrato das folhas de Morus nigra durante o transporte na sobrevivência e apoptose de folículos pré-antrais in vitro. A CLAE (Cromatografia Líquida de Alta Eficiência) foi usada para determinar a impressão digital cromatográfica do extrato etanólico. Foram coletados 4 pares de ovários de 4 ovelhas. O córtex ovariano foi fragmentado e um dos fragmentos foi fixado em formaldeído tamponado a $10 \%$ e destinado às análises histológica e de TUNEL (controle fresco). Os demais fragmentos foram colocados em Meio Essencial Mínimo (MEM - meio controle) ou extrato de $M$. nigra $(0,025,0,05$ ou $0,1 \mathrm{mg} / \mathrm{mL})$ e conservados (simulando transporte) à $4{ }^{\circ} \mathrm{C}$ por 6,12 ou $24 \mathrm{~h}$. Os fragmentos conservados $(6 \mathrm{~h})$ também foram destinados às análises histológica e de TUNEL. A análise de CLAE confirmou a presença de compostos antioxidantes (rutina, isoquercetina e canferitrina) no extrato. Houve uma redução $(P<0,05)$ na percentagem de folículos pré-antrais morfologicamente normais após conservação em todos os tratamentos em comparação com o controle fresco. A percentagem de folículos pré-antrais normais após conservação em $M$. nigra a $0,05 \mathrm{mg} / \mathrm{mL}$ por $6 \mathrm{~h}$ foi maior $(\mathrm{P}<0,05)$ do que em MEM ou M. nigra a $0,025 \mathrm{mg} / \mathrm{mL}$ e similar $(\mathrm{P}>0,05)$ ao extrato a $0,1 \mathrm{mg} / \mathrm{mL}$. A apoptose aumentou $(\mathrm{P}<0,05)$ após conservação durante $6 \mathrm{~h}$ em todos os tratamentos em comparação com o controle fresco. Além disso, as células TUNEL positivas diminuíram $(\mathrm{P}<0,05)$, após conservação em 0,05 ou $0,1 \mathrm{mg} / \mathrm{mL}$ de $M$. nigra em comparação com MEM ou $0,025 \mathrm{mg} / \mathrm{mL}$ de M. nigra. Em conclusão, $0,05 \mathrm{mg} / \mathrm{mL}$ de $M$. nigra pode ser usado como meio de conservação de tecido ovariano ovino a $4{ }^{\circ} \mathrm{C}$ durante até $6 \mathrm{~h}$.
\end{abstract}

Palavras-chave: Ovino. Oócito. Pré-antral. CLAE. Planta Medicinal.

\section{Introduction}

Temporal storage of ovaries during transportation to the specialized laboratories can provide opportunities to rescue oocytes from ovaries of livestock or endangered animals that could be used for embryo production in vitro. Adequate medium, duration of storage and temperature at which ovaries are kept after death or excision may affect the potential of oocytes recovered from the ovaries (HIDEAKI et al., 2007).

Studies have demonstrated that storage of ovine and caprine ovarian fragments at $4{ }^{\circ} \mathrm{C}$ results in proper rates of morphologically normal follicles compared to higher temperatures such as 20 or $35{ }^{\circ} \mathrm{C}$ (ANDRADE et al., 2001; MATOS et al., 2004; COSTA et al., 2005). Chaves et al. (2008) have shown that ovarian tissue transportation in Minimal Essential Medium (MEM) at $4{ }^{\circ} \mathrm{C}$ for up to $4 \mathrm{~h}$ maintained the percentages of morphologically normal follicles similar to those observed in fresh tissues even after 7 days of in vitro culture. However, the use of synthetic media (e.g. MEM) could be expensive and less accessible. Therefore, the use of alternative media, such as medicinal plant extracts, may be a promising and lowcost strategy for temporal storage of mammalian ovaries (GOUVEIA et al., 2015), especially due to the remarkable cytoprotective and antioxidant characteristics of these plants (TAG, 2015).

Morus nigra L. (mulberry) is a plant found from temperate to subtropical regions of the Northern hemisphere to the tropics of the Southern hemisphere and it can grow in a wide range of climatic, topographic and soil conditions (ERCISLI; ORHAN, 2007). In Northeastern Brazil, it is popularly known as "amora-miúra", "amora-preta" or "amoreira". The mulberry belongs to the genus Morus of the family Moraceae (ALMEIDA et al., 2011) and has been widely used in folk medicine as hepatoprotective, hypotensive, antipyretic, analgesic, diuretic, expectorant and antidiabetic (NOMURA, 1988; CHEN et al., 1995). Several compounds have been isolated from the roots, trunk bark and leaves of $M$. nigra, such as the piperidine alkaloid (moranoline), glycoproteins and phenolic compounds (flavonoids, stilbenes, coumarins) (NOMURA; HANO, 1994; KIM et al., 1999; TOSHIO et al., 2005; MAZIMBA et al., 2011). Some of these compounds (for example, flavonoids) 
have antioxidant properties, reducing oxidative stress, reactive oxygen species (ROS) levels, lipid peroxidation and DNA damage in different cell types (MAZIMBA et al., 2011; VOLPATO et al., 2011; MATA-CAMPUZANO et al., 2012).

The leaves of M. nigra are commonly used by women in menopause as a substitute for the conventional hormonal replacement therapy, with a similar effect to that obtained after estrogen use (SILVA et al., 2003). Nevertheless, a recent study demonstrated that the administration of $M$. nigra did not exhibit any estrogenic activity nor did exert a toxic effect on the female reproductive system and on the embryonic development of rats (QUEIROZ et al., 2012). Moreover, no biochemical and macroscopic changes were observed after 30 days of $M$. nigra administration in rats, thus demonstrating its low toxicity (OLIVEIRA et al., 2013).

Thus, in view of its distribution throughout the world, $M$. nigra extract may be used as an alternative and a low-cost (it would cost about 10 or 40 times less than MEM or $\alpha$-MEM, respectively) preservation medium in the transportation of ovine ovarian tissue. However, there were no reports of the use of $M$. nigra extract as an in vitro preservation medium for sheep ovaries. The aim of the present study was to determine if the use of $M$. nigra extract as a preservation medium during ovine ovarian tissue transportation at $4^{\circ} \mathrm{C}$ would influence on the morphology and apoptosis of preantral follicles in vitro.

\section{Material and Methods}

This experimental was approved and performed under the guidelines of Committee of Ethics and Deontology Studies and Research at the Federal University of San Francisco Valley (protocol $n^{\circ}$ 0007/040713). Unless indicated, chemicals used in the present study were purchased from Sigma Chemical Co. (St. Louis, MO, USA).

\section{Plant material and extract preparation}

Fresh leaves of $M$. nigra were collected in Petrolina-PE, $\left(09^{\circ} 23^{\prime} 55^{\prime \prime}\right.$ South and $38^{\circ}-40^{\circ} 30^{\prime}$ 03" West, Pernambuco, Brazil), from the Caatinga biome, and characterized by a semiarid climate, with average annual temperature of $26.4{ }^{\circ} \mathrm{C}$. A voucher specimen (1764) is deposited at the Herbário Vale do São Francisco (HVASF) of the Federal University of San Francisco Valley. The leaves were dried in an oven at $40^{\circ} \mathrm{C}$ and pulverized and extracted at room temperature with $95 \%$ ethanol (Vetec, Duque de Caxias-RJ, Brazil) for $72 \mathrm{~h}$. The extract was dried at $45^{\circ} \mathrm{C}$ for some hours under vacuum using rotavapor and the yield was approximately of $10 \%$ obtaining the crude ethanolic extract of the leaves of Morus nigra, which was dissolved in $0.9 \%$ saline solution, corresponding to concentrations of $0.025 ; 0.05$ or $0.1 \mathrm{mg} / \mathrm{mL}$.

Analysis of ethanolic extract by High Performance Liquid Chromatography (HPLC)

Chromatographic equipment consisted of a Shimadzu ${ }^{\circledR}$ (Shimadzu, Kyoto, Japan) liquid chromatograph equipped with a diode array detector (DAD), with a quaternary system of pumps model LC-20ADVP, degasser model DGU-20A, detector PDA model SPD-20AVP, oven model CTO20ASVP, auto sampler injector model SIL-20ADVP and controller SCL-20AVP. The data was acquired and processed using Shimadzu ${ }^{\circledR}$ LC solution 1.0 software (Japan).

The crude ethanolic extract $(0.1 \mathrm{mg} / \mathrm{mL})$ and chemicals reference (RUT - rutin, ISO-isoquercetin and KFT - kaempferitrin at concentrations of 15 , $20,30,50$ and $100 \mu \mathrm{g} / \mathrm{mL}$ ) alone were subjected to analysis, under the following conditions: stationary phase consisted of a C18 column $(250 \times 4.6 \mathrm{~mm}, 5$ $\mu \mathrm{m})$, Supelco ${ }^{\circledR}$ (Supelco, Bellefonte, USA), at $37^{\circ} \mathrm{C}$ with a sample injection volume of $20 \mu \mathrm{l}$ and the wavelength was $340 \mathrm{~nm}$. Solvent A: water $+0.01 \%$ trifluoroacetic acid (v/v) and solution B: acetonitrile was used as mobile phase $(0.8 \mathrm{~mL} / \mathrm{min})$ with a 
gradient program of: 35 to $65 \% \mathrm{~B}$ in $25 \mathrm{~min}, 65$ to $85 \% \mathrm{~B}$ in $15 \mathrm{~min}, 85$ to $100 \% \mathrm{~B}$ in $5 \mathrm{~min}$, returning to $35 \% \mathrm{~B}$ after $10 \mathrm{~min}$. All solutions were degassed and filtered through a membrane filter of $0.20 \mu \mathrm{M}$ pore (Millipore, Bedford, USA).

\section{Ovaries collection and in vitro preservation}

Ovarian cortical tissues ( $\mathrm{n}=8$ ovaries) were collected at a local abattoir from four adult $(1-3$ years old) mixed-breed sheep. Immediately postmortem, pairs of ovaries were washed once in 70\% alcohol (Dinâmica) and then twice in MEM buffered with HEPES (MEM-HEPES) and supplemented with antibiotics $(100 \mu \mathrm{g} / \mathrm{mL}$ penicillin and $100 \mu \mathrm{g} / \mathrm{mL}$ streptomycin).
Still in the slaughterhouse, the pair of ovaries from each animal were cut in half, after which the medulla, large antral follicles, and corpora lutea were removed. Following this, the ovarian cortex was divided into 13 fragments approximately $3 \times 3 \mathrm{~mm}$ ( $1 \mathrm{~mm}$ thick). Then, one ovarian fragment was taken randomly and fixed for histological and TUNEL analyses (fresh control). The other 12 fragments were randomly placed into tubes containing $5 \mathrm{~mL}$ MEM supplemented with antibiotics $(100 \mu \mathrm{g} / \mathrm{mL}$ penicillin and $100 \mu \mathrm{g} / \mathrm{mL}$ streptomycin; control medium; CHAVES et al., 2008) or different concentrations of $M$. nigra extract $(0.025 ; 0.5$ or $0.1 \mathrm{mg} / \mathrm{mL}$ ), obtained from the dilution in $0.9 \%$ saline solution, and stored at $4^{\circ} \mathrm{C}$ for 6,12 or $24 \mathrm{~h}$ (simulating transport) (Figure 1). The temperature was maintained using thermos boxes with ice. Each treatment was repeated 4 times.

Figure 1. General experimental protocol for the preservation of ovine preantral follicles in Morus nigra extract. MN: M. nigra leaf extract.

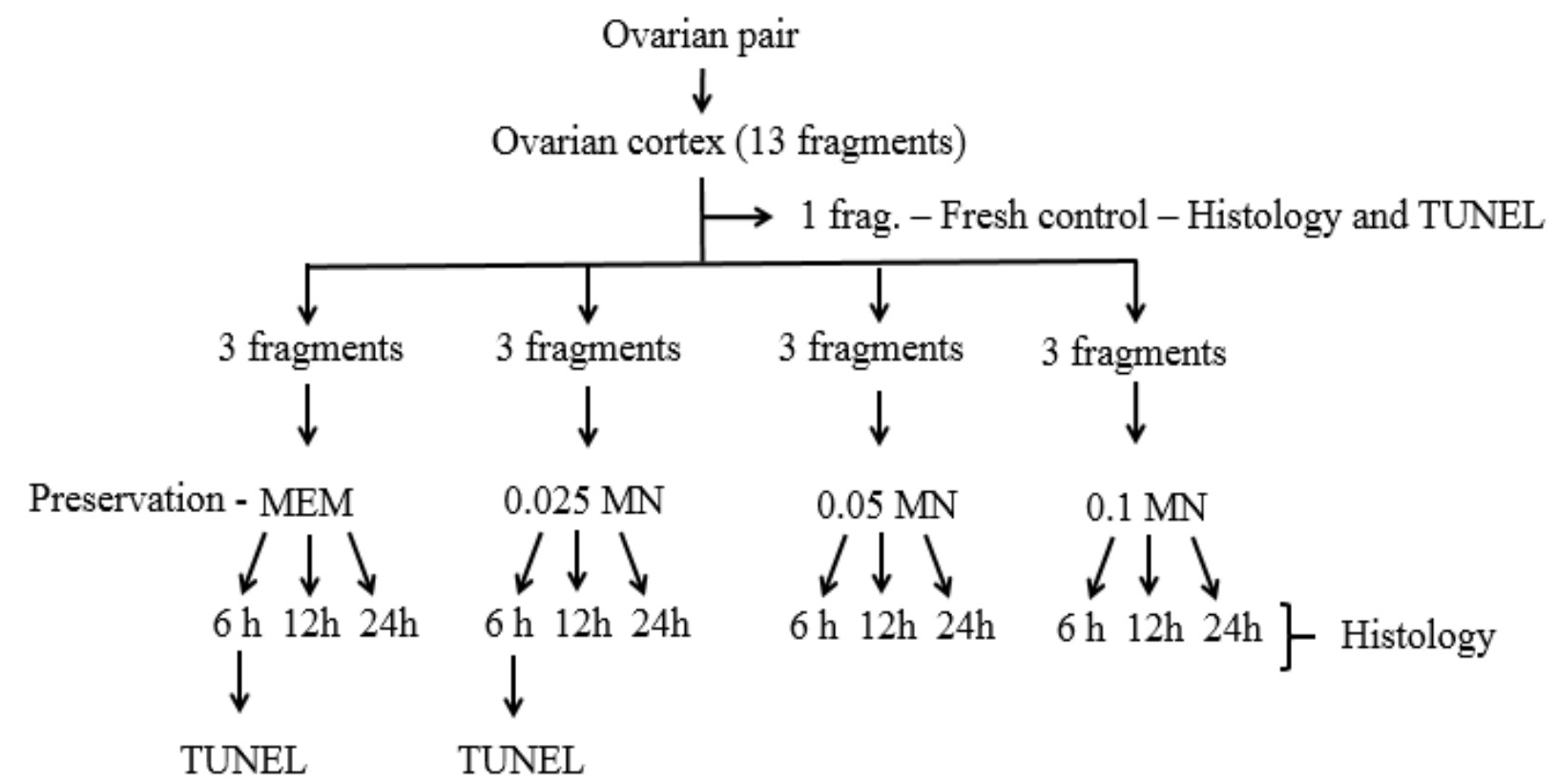

Morphological analysis of preantral follicles preserved in situ

Ovarian fragments from each treatment, including the fresh control, were fixed individually in $10 \%$ buffered formaldehyde (Dinâmica, Diadema, São
Paulo, Brazil) for $18 \mathrm{~h}$. Subsequently, fragments were dehydrated in a graded series of ethanol (Dinâmica), clarified with xylene (Dinâmica) and embedded in paraffin wax (Dinâmica). Tissues were sectioned serially at a thickness of $5 \mu \mathrm{m}$ and sections were 
stained using standard protocols with hematoxylin eosin (Vetec, Duque de Caxias-RJ, Brazil). Sections were examined by light microscopy (Nikon, Tokyo, Japan) at $400 \times$ magnification. Preantral follicles were counted and evaluated in the section where the oocyte nucleus was visible.

The developmental stages of preantral follicles have been defined previously (SILVA et al., 2004) as primordial (one layer of flattened granulosa cells around the oocyte) or growing follicles (intermediate: one layer of flattened to cuboidal granulosa cells; primary: one layer of cuboidal granulosa cells, and secondary: two or more layers of cuboidal granulosa cells around the oocyte). Additionally, these follicles were classified individually as histologically normal when an intact oocyte was present and surrounded by granulosa cells that are well organized in one or more layers and have no pyknotic nuclei. Atretic follicles were defined as those with a retracted oocyte, pyknotic nucleus, and/or disorganized granulosa cells detached from the basement membrane. Overall, 120 follicles were evaluated for each treatment (30 follicles per treatment $\mathrm{x} 4$ replicates $=120$ follicles), totaling 1,560 preantral follicles.

\section{Detection of apoptotic cells by TUNEL Assay}

Terminal deoxynucleotidyl transferase (TdT) mediated dUTP nick-end labeling (TUNEL) assay was used for a more in-depth evaluation of ovine preantral follicle quality before (fresh control) and after preservation in MEM or $0.025,0.05$ or 0,1 $\mathrm{mg} / \mathrm{mL}$ of $M$. nigra for $6 \mathrm{~h}$. TUNEL was performed using a commercial kit (In Situ Cell Death Detection Kit, Roche Diagnostics Ltd., Indianapolis, USA) following the manufacturer's protocol, with some modifications. Briefly, sections $(5 \mu \mathrm{m})$ mounted on glass slides were deparaffinized and rehydrated through graded alcohols, then rinsed in PBS $(\mathrm{pH}$ 7.2). The slides were incubated in citrate buffer (Dinâmica) at $95^{\circ} \mathrm{C}$ in a deckloaking chamber for $40 \mathrm{~min}$ to retrieve antigenicity, and endogenous peroxidase activity was prevented by incubation with $3 \% \mathrm{H}_{2} \mathrm{O}_{2}$ (Dinâmica) and methyl ethanol (QEEL, São Paulo, Brazil) for 10 min. After rinsing in Tris buffer (Dinâmica), the sections were incubated with TUNEL reaction mixture at $37^{\circ} \mathrm{C}$ for $1 \mathrm{~h}$. Then, the specimens were incubated with Converter-POD in a humidified chamber at $37{ }^{\circ} \mathrm{C}$ for $30 \mathrm{~min}$. The DNA fragmentation was revealed by incubation of the tissues with diaminobenzidine (DAB; $0.05 \% \mathrm{DAB}$ in Tris/ $\mathrm{HCl} \mathrm{pH} 7.6,0.03 \% \mathrm{H}_{2} \mathrm{O}_{2}$ ) during $1 \mathrm{~min}$. Finally, sections were counterstained with Harry's hematoxylin in a dark chamber at room temperature for $1 \mathrm{~min}$, dehydrated in ethanol, cleared in xylene, and mounted with balsam (Dinâmica). For negative controls (reaction controls), slides were incubated with label solution (without terminal deoxynucleotidyl transferase enzyme) instead of TUNEL reaction mixture.

Preantral follicles apoptosis was evaluated as described previously (SANTOS et al., 2014). Only follicles that contained an oocyte nucleus were analyzed for apoptotic assay. The number of brown TUNEL positive cells (oocyte and granulosa cells) was counted in ten randomly fields per treatment using Image-Pro Plus ${ }^{\circledR}$ software. The percentage of TUNEL-positive or apoptotic cells was calculated as the number of apoptotic cells out of the total number of cells (x 100).

\section{Statistical analysis}

Percentages of morphologically normal were submitted to the Shapiro-Wilk test to verify normal distribution of residues and homogeneity of variances, followed by ANOVA and the Bonferroni's test was applied for comparison among treatments. Values of apoptotic cells were submitted to Quisquare test and differences were considered to be statistically significant when $\mathrm{P}<0.05$. The results of follicular survival were expressed as the mean $\pm \mathrm{SD}$. The values have been verified using the software BioEstat 5.0. 


\section{Results}

\section{HPLC analysis}

After analysis of the crude ethanolic extract through the HPLC method, it was possible to verify the presence of three substances with different retention times: rutin (A) in $28 \mathrm{~min}(\lambda$
$=252 / 354 \mathrm{~nm})$, isoquercetin (B) in $29 \min (\lambda=$ $253 / 354 \mathrm{~nm})$ and kaempferitrin (C) in $31 \mathrm{~min}(\lambda=$ $247 / 354 \mathrm{~nm}$; Figure 2). Among these substances, it was possible to accurately quantify rutin $(5.05 \pm 1.3$ $\mu \mathrm{g} / \mathrm{mL})$ and isoquercetin $(22.3 \pm 3.02 \mu \mathrm{g} / \mathrm{mL})$. The chemical structures of the compounds are shown in the figure 3 .

Figure 2. High performance liquid chromatography with diode array detector (HPLC-DAD) profiles of Morus nigra ethanolic extract.

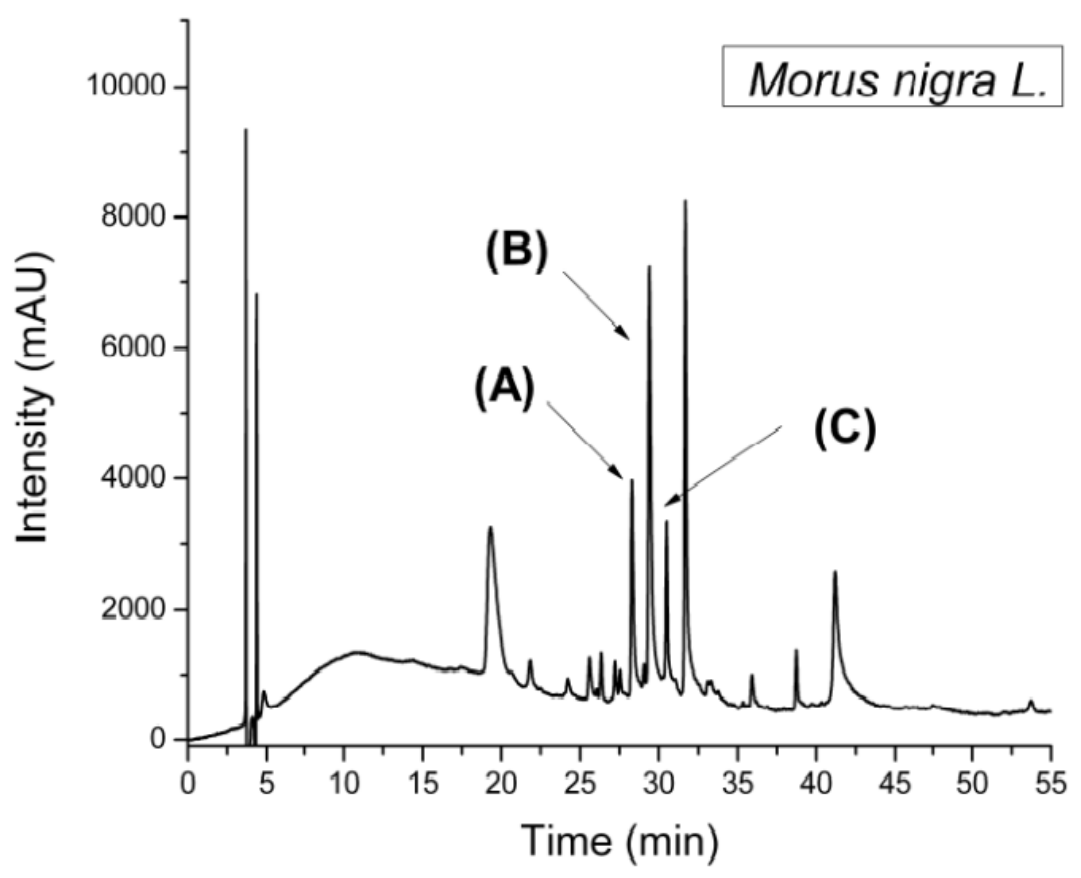


Figure 3. Chemical structures of the flavonoids rutin (A), isoquercetin (B) and kaempferitrin (C).

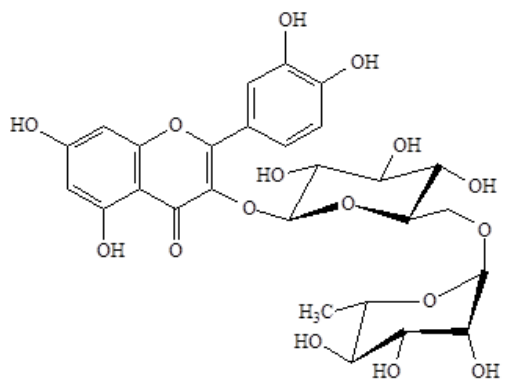

(A)<smiles>O=c1c(OC(O)C(O)C(O)C(O)CO)c(-c2ccc(O)c(O)c2)oc2cc(O)cc(O)c12</smiles>

(B)

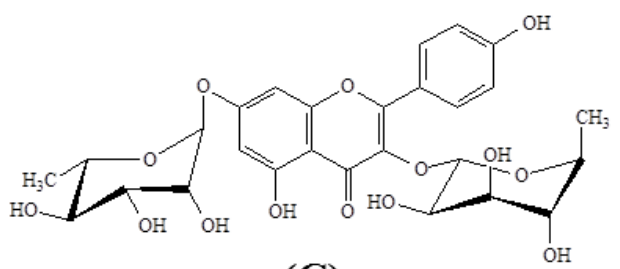

(C)

Effect of storage conditions on follicular morphology

Among the preantral follicles analyzed, 876 were primordial, 645 intermediate, 18 primary and 21 secondary follicles. The preantral follicles in the fresh control (Figure. 4A) and those preserved in $0.05 \mathrm{mg} / \mathrm{mL}$ de $M$. nigra (Figure 4B) for $6 \mathrm{~h}$ showed centrally located oocytes and organized granulosa cells surrounded by normal intact basement membranes. After storage in $0.1 \mathrm{mg} / \mathrm{mL} M$. nigra for $12 \mathrm{~h}$, atretic follicles with a retracted oocyte and disorganized granulosa cells could be observed (Figure 4C).

Figure 4. Histological sections of ovine ovarian fragments showing morphologically normal follicles in the fresh control (A) and after $6 \mathrm{~h}$ of preservation in $0.05 \mathrm{mg} / \mathrm{mL} \mathrm{M.} \mathrm{nigra} \mathrm{(B);} \mathrm{atretic} \mathrm{follicle} \mathrm{after} 12 \mathrm{~h}$ of preservation in 0.1 $\mathrm{mg} / \mathrm{mL}$ M. nigra (C). Hematoxylin-eosin stain. $\mathrm{O}=$ oocyte; $\mathrm{GC}=$ granulosa cell. Scale bar: Fig A: $80 \mu \mathrm{m}(100 \mathrm{x})$; B e C: $40 \mu \mathrm{m}(400 \mathrm{x})$.
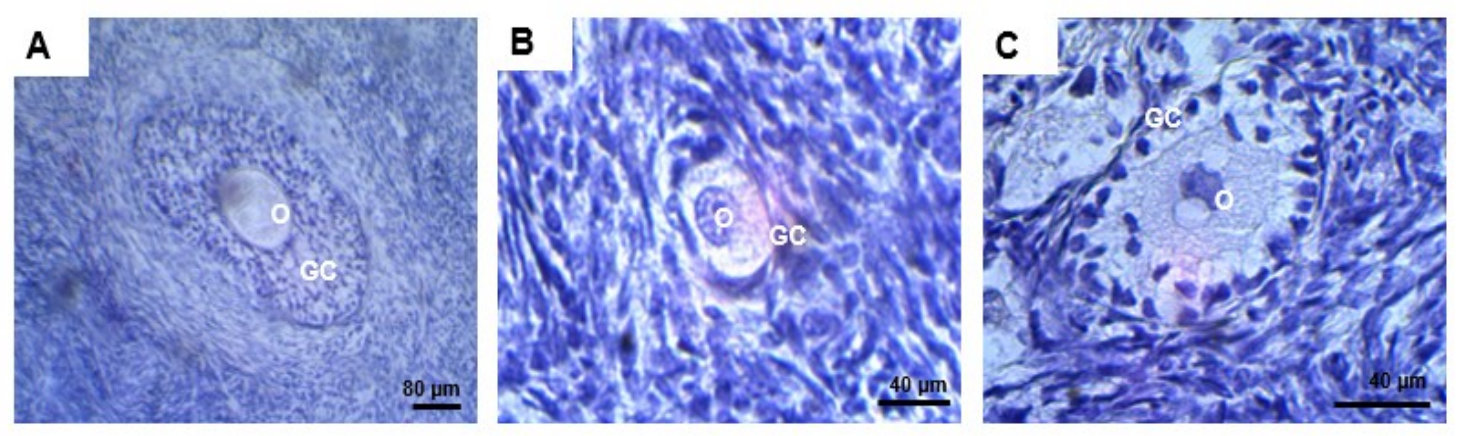
Figure 5 details the effect of media and preservation period of ovarian fragments on the percentage of normal preantral follicles. After histological analysis, there were $71.5 \%$ normal preantral follicles in the fresh control. There was a significant reduction in the percentage of morphologically normal follicles after preservation in all treatments $(\mathrm{P}<0.05)$ compared to the fresh control. Comparing the different media in the same period, the percentage of normal preantral follicles after preservation in $M$. nigra at $0.05 \mathrm{mg} / \mathrm{mL}$ for 6 h $(54 \%)$ was significantly higher $(\mathrm{P}<0.05)$ than in MEM (32\%) or $0.025 \mathrm{mg} / \mathrm{mL}$ M. nigra $(32.5 \%)$ and similar $(\mathrm{P}>0.05)$ to $0.1 \mathrm{mg} / \mathrm{mL}$ of the extract (45.75\%). Comparing the control medium (MEM) with any concentration of $M$. nigra extract, no difference was observed after 12 or $24 \mathrm{~h}$ of storage $(\mathrm{P}>0.05)$.

Figure 5. Percentages (mean \pm SEM) of morphologically normal follicles in the fresh control and after preservation in MEM or M. nigra extract.

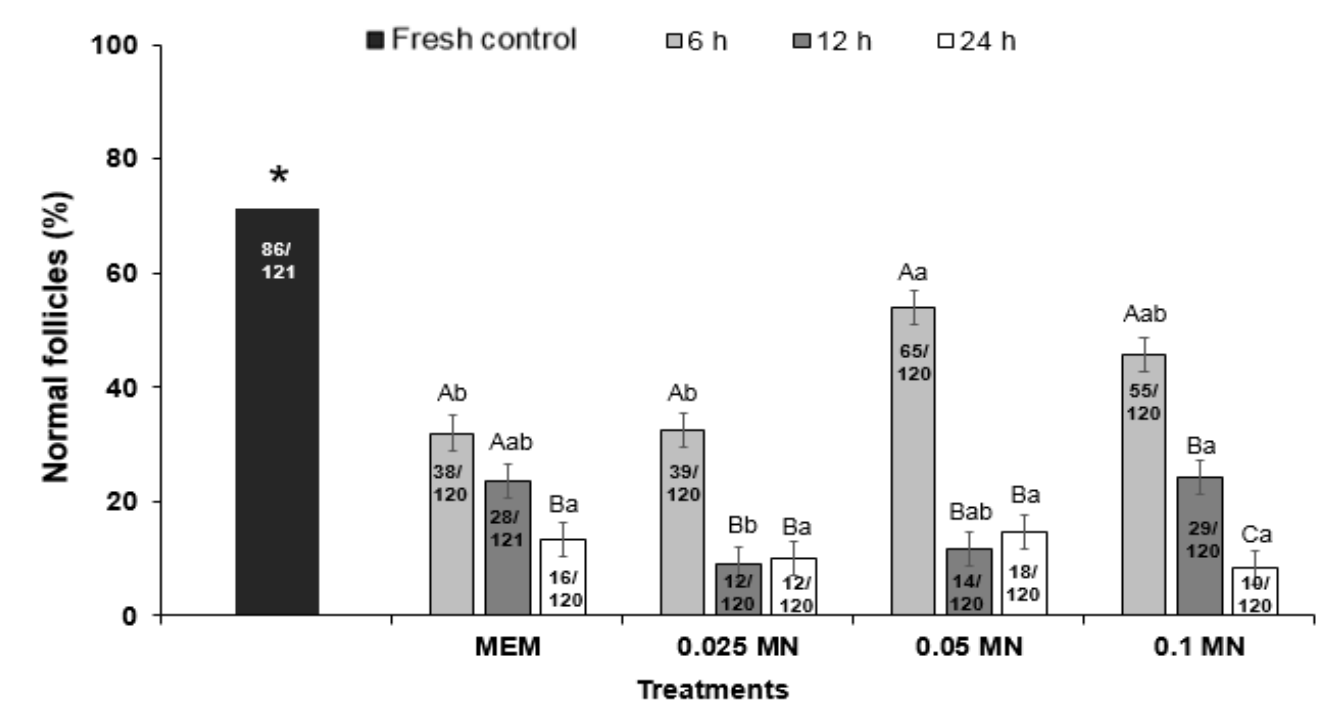

*Differs significantly from fresh control $(\mathrm{P}<0.05)$. (a,b) Different letters denote significant differences among treatments (different media) in the same period $(\mathrm{P}<0.05)$.

(A, B) Different letters denote significant differences among periods in the vsame media $(\mathrm{P}<0.05)$.

\section{Apoptotic cell detection}

TUNEL analysis was performed only for the period of $6 \mathrm{~h}$ of preservation because at this period $M$. nigra extract $(0.05 \mathrm{mg} / \mathrm{mL})$ had higher percentages of normal follicles than the control medium. There was a significant increase $(\mathrm{P}<0.05)$ in the percentage of apoptotic cells (oocyte and granulosa cells) after preservation in all treatments compared with the fresh control (14.5\%) (Figure 6). Ovarian tissue preserved at $0.05 \mathrm{mg} / \mathrm{mL}(38 \%)$ or $0.1 \mathrm{mg} /$ $\mathrm{mL}(43 \%)$ M. nigra extract showed less apoptotic cells than storage in MEM (67\%) or $0.025 \mathrm{mg} / \mathrm{mL}$
(69.5\%) M. nigra extract $(\mathrm{P}<0.05)$. No difference was observed in the percentage of TUNEL-positive cells after preservation in $0.05 \mathrm{mg} / \mathrm{mL}$ or $0.1 \mathrm{mg}$ / $\mathrm{mL} M$. nigra extract $(\mathrm{P}>0.05)$.

Ovarian follicles preserved in $0.05 \mathrm{mg} / \mathrm{mL} M$. nigra did not show or showed less apoptotic cells (Figure 7A). Nevertheless, TUNEL-positive cells (brown staining) were commonly found in ovarian tissue that had been preserved in MEM (Fig. 7B). Negative control did not show staining for TUNEL analysis (Figure 7C). 
Figure 6. Percentages (mean \pm SEM) of TUNEL positive cells in the fresh control and after 6 hours of preservation in MEM; $0.025 ; 0.05$ or $0.1 \mathrm{mg} / \mathrm{mL}$ M. nigra.

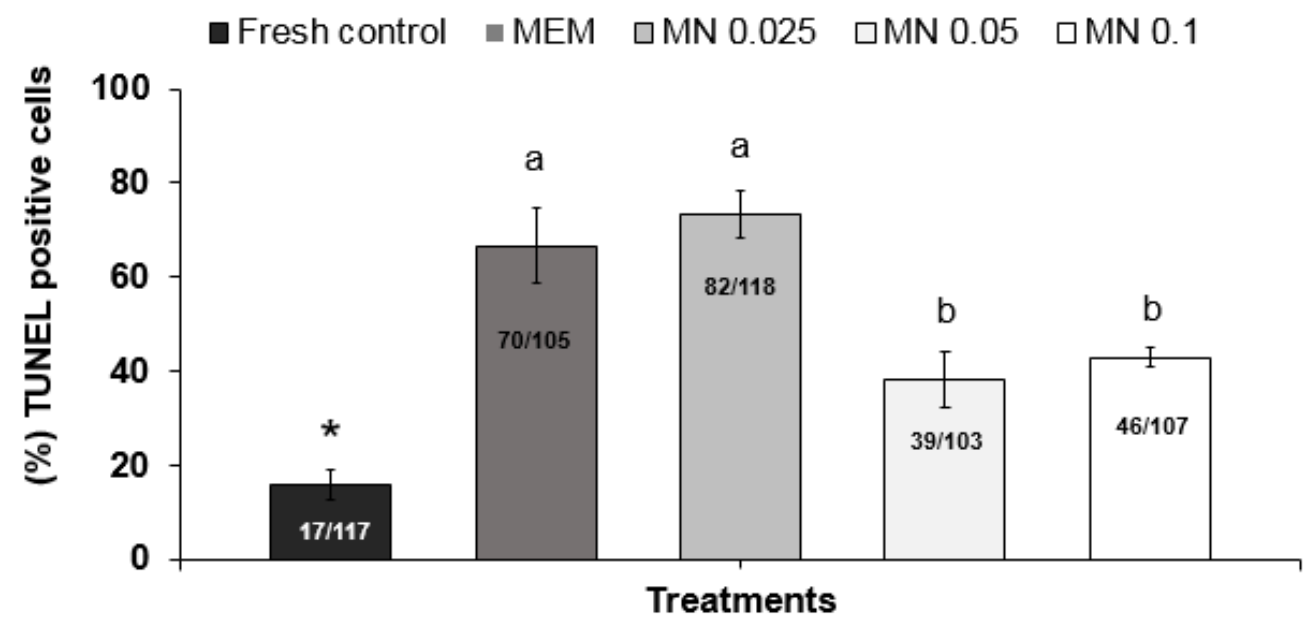

*Differs significantly from fresh control $(\mathrm{P}<0.05)$.

$(\mathrm{a}, \mathrm{b})$ Different letters denote significant differences among treatments (different media) $(\mathrm{P}<0.05)$.

Figure 7. Apoptosis detection in ovine ovarian tissue after $6 \mathrm{~h}$ of preservation. Normal preantral follicle in $0.05 \mathrm{mg} /$ $\mathrm{mL}$ M. nigra (A), apoptotic follicles in MEM (B), and negative control (C). Note the apoptosis in the oocyte and granulosa cells (brown) in figure B. O: oocyte; GC: granulosa cells. Scale bar: $30 \mu \mathrm{m}(400 \mathrm{x})$.
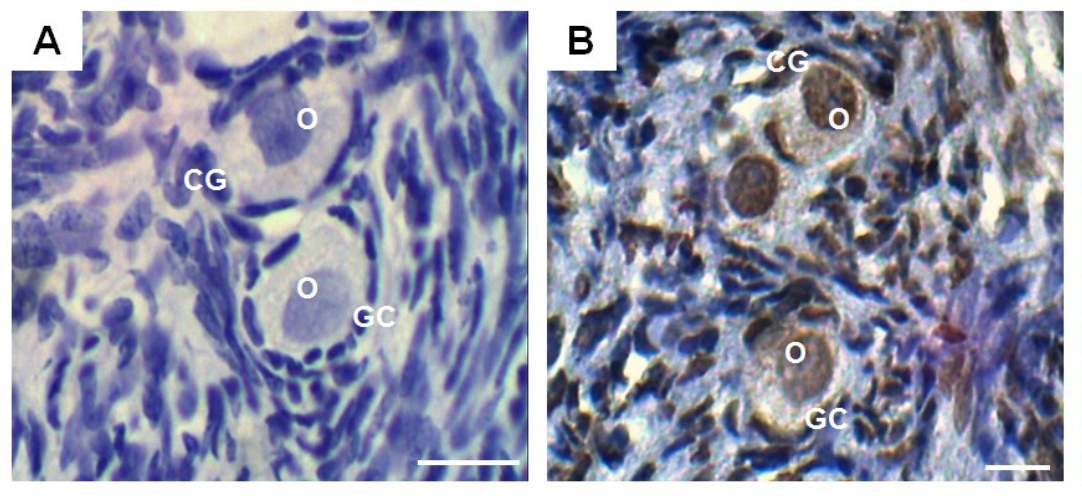

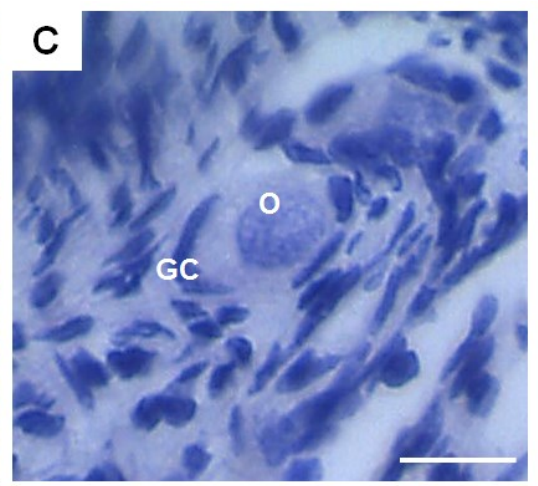

\section{Discussion}

This is the first report to demonstrate the beneficial effect of $M$. nigra extract on in vitro preservation of ovine ovarian tissue during transportation. One of the main challenges of the researches is to find the optimum composition for a storage solution, which might have less toxicity or damage for ovarian tissue. In this context, many studies have been performed to evaluate the efficiency of different solutions (MEM: CHAVES et al., 2008; saline solution: ANDRADE et al., 2002; Braun Collins solution: SILVA et al., 2000; coconut water solution:
ANDRADE et al., 2002; PBS: SANTOS et al., 2002) in the maintenance of follicle survival during the transport of the ovaries. Among these media, MEM has been one of the most commonly used for ovary storage in ovine and caprine species. MEM is rich in nutrients (glucose, vitamins and amino acids) and could be used alone (caprine: CHAVES et al., 2008) or enriched with others supplements (e.g. ITS, glutamine, hypoxanthine, and BSA; ovine: GONÇALVES et al., 2015) for maintaining follicle viability in ovarian tissue transportation. However, the use of commercial medium and/or 
supplements makes the reproductive techniques more expensive. Therefore, other alternative media, such as Amburana cearensis extract, have also been successfully used to preserve caprine ovarian tissue at $4^{\circ} \mathrm{C}$ for $6 \mathrm{~h}$ (GOUVEIA et al., 2015), maintaining the percentages of normal follicles (approximately $60 \%$ ) similar to that observed in the control medium (MEM).

In our study, after $6 \mathrm{~h}$ of preservation, an appropriate concentration of $M$. nigra extract $(0.05 \mathrm{mg} / \mathrm{mL})$ resulted in higher percentages of morphologically normal follicles $(54.0 \%)$ and lower rates of DNA fragmentation (38.23\%) than those observed in the control medium (MEM) or in $0.025 \mathrm{mg} / \mathrm{mL}$ M. nigra. Using the HPLC method, it was possible to identify three substances (rutin, isoquercetin, and kaempferitrin) in the crude ethanolic extract of $M$. nigra. We should take into account that environments in which the plant develops (temperature, relative humidity, solar radiation, soil) exert a direct influence on the chemical composition of the extracts (SUAREZ et al., 2003; FLOSS, 2004). Thus, knowledge of the chemical composition of $M$. nigra extract is essential for obtaining standardized extracts, which could be used as a commercial medium in the future.

In the current study, the substances identified in the $M$. nigra extract are flavonoids, a large group of polyphenolic compound found in many plant-based foods (MORETTI et al., 2012). The flavonoids exert antioxidant properties, which have been attributed to the ability of scavenging ROS. A relation between the chemical nature of flavonoids and their antioxidant activity has been established; in particular the number and the position of hydroxyl groups influence their antioxidant power (ÇELIK; ARINÇ, 2010). As they are amphipathic molecules, their permeability across membranes and their membrane affinity depend on the degree of hydroxylation, molecular configuration, and the length of the side chain (TAMMELA et al., 2004).

Our HPLC analysis showed that the compound found in large amounts in the $M$. nigra extract was isoquercetin, which is a quercetin glycoside, a flavonoid present in plants (WANG et al., 2013). Isoquercetin has many biological properties, including antiviral (KIM et al., 2010) and antidiabetic (ZHANG et al., 2011). To date, there were no reports of the use of isoquercetin on folliculogenesis. However, its antioxidant effect was observed in other cells. Studies have demonstrated that isoquercetin protects neuroblastome (SHSY5Y) from the oxidative damage in vitro (SOUNDARARAJAN et al., 2008). In addition, isoquercetin is a potent neuroprotector in rats, being described as anti-inflammatory and antiapoptotic factor (WANG et al., 2013).

Rutin is also a glycoside of quercetin, in which the 3-hydroxyl group is replaced with rutinose, a disaccharide consisting of glucose and rhamnose (WEI et al., 2011). This flavonoid has antioxidant, anti-inflammatory and anti-cancer properties (SHEN et al., 2004). Rutin has been used to reduce the injury caused by isquemy/reperfusion in different organs, such as heart, brain and testes (JEONG et al., 2009; GUPTA et al., 2003; WEI et al., 2011). Recently, a study has shown that rutin decreases lipid peroxidation, ROS and DNA fragmentation in thawed deer spermatozoa after incubation at $37^{\circ} \mathrm{C}$ (MATA-CAMPUZANO et al., 2012). Other authors demonstrated that rutin preserves the viability and motility of human spermatozoa when used in the sperm selection by swim-up procedure (MORETTI et al., 2012), besides being able to replace the addition of transferrin, selenium and ascorbic acid during 12-days in vitro culture of ovine secondary follicles, maintaining follicular viability and increasing GSH levels (LINS et al., 2017).

Another compound found in the M. nigra extract was the kaempferitrin, which is naturally occurring kaempferol glycoside, isolated from several plants (PEREIRA et al, 2011; ALONSOCASTRO et al., 2013) and from fungus Boverivar microspora Annulohypoxylon (CHENG et al., 2011). Besides its antibacterial (DALMARCO et 
al., 2010), antinociceptive and anti-inflammatory effects (DE MELO et al., 2009), kaempferitrin exerts antioxidant activity with similar potential to quercetin (DE SOUSA et al., 2004). Kaempferitrin also inhibits myeloperoxidase, a cytosolic enzyme, which participates in ROS production in neutrophils (REGASINI et al., 2008).

Therefore, in our study, it can be suggested that these three natural antioxidants may act isolated or in association to reduce the apoptosis of ovine preantral follicles preserved in $M$. nigra extract for $6 \mathrm{~h}$. Moreover, the temperature $\left(4^{\circ} \mathrm{C}\right)$ used for preservation may also help to support the survival through a reduction in cell metabolism. However, the same concentrations of $M$. nigra extract were not sufficient for maintaining healthy follicles for $12 \mathrm{~h}$ or more. The follicles may need energetic substrates or other substances, like growth factors or hormones, to keep normal morphology for longer periods. Nevertheless, $0.025 \mathrm{mg} / \mathrm{mL} M$. nigra seems to be insufficient to maintain follicular viability even for a short period $(6 \mathrm{~h})$.

It is important to note that the costs for purchasing the medium containing $M$. nigra extract may make in vitro preservation studies cheaper and accessible. These costs were limited to acquisition of $95 \%$ ethanol and $0.9 \%$ saline solution for extract dilution. Adversely, MEM is an expensive commercial medium that would cost about 10 times more than plant extract.

\section{Conclusions}

Ovine preantral follicles can be successfully preserved in $M$. nigra extract at $4^{\circ} \mathrm{C}$ for up to $6 \mathrm{~h}$. Therefore, due to the higher cost of MEM, the use of $M$. nigra extract $(0.05 \mathrm{mg} / \mathrm{mL})$ as a preservation medium is recommended. In future studies, we also suggest that the flavonoids identified in the $M$. nigra extract should be used alone to verify their antiapoptotic potential after ovaries storage.

\section{Acknowledgements}

A.Y.P. Cavalcante receives a scholarship from FACEPE. M.H.T. Matos is supported by a grant from National Council for Scientific and Technological Development (CNPq).

\section{References}

ALMEIDA, J. R. G. S.; GUIMARÃES, A. L.; OLIVEIRA, A. P.; ARAÚJO, E. C. C.; SILVA, F. S.; NEVES, L. F.; OLIVEIRA, R. A.; SÁ, P. G. S.; QUINTANS-JÚNIOR, L. J. Evaluation of Hypoglycemic Potential and PreClinical Toxicology of Morus nigra L. (Moraceae). Latin American Journal of Pharmacy, Buenos Aires, v. 30, n. 1, p. 96-100, 2011.

ALONSO-CASTRO, A. J.; ORTIZ-SÁNCHEZ, E.; GARCÍA-REGALADO, A.; RUIZ, G.; NÚÑEZMARTÍNEZ, J. M.; GONZÁLEZ-SÁNCHEZ, I.; QUITANAR-JURADO, V.; MORALES-SANCHEZ, E.; DOMINGUES, F.; LÓPEZ-TOLEDO, G.; CERBÓN, M. A.; GARCÍA-CARRANCÁ, A. Kaempferitrin induces apoptosis via intrinsic pathway in HeLa cells and exerts antitumor effects. Journal of Ethnopharmacology, Limerick, v. 145, n. 2, p.476-489, 2013.

ANDRADE, E. R.; RODRIGUES, A. P. R.; AMORIM, C. A.; CARVALHO, F. C.; DODE, M. A. N.; FIGUEIREDO, J. R. Short term maintenance of sheep preantral follicles in situ in $0.9 \%$ saline and Braun-Collins solution. Small Ruminant Research, Little Rock, v. 41, n. 2, p. 141-149, 2001.

ANDRADE, E. R.; AMORIM, C. A.; COSTA, S. H. F.; FERREIRA, M. A. L.; RODRIGUES, A. P. R.; DODE, M. A. N. Preliminar study of short-term preservation of ovine ovarian tissue containing preantral follicles in saline solution or TCM 199. Veterinary Record, London, v. 151, n. 15 , p. $452-453,2002$.

ÇELIK, H.; ARINÇ, E. Evaluation of the protective effects of quercetin, rutin, naringenin, resveratrol and trolox against idarubicin-induced DNA damage. Journal of Pharmacy \& Pharmaceutical Sciences, Edmonton, v. 13, n. 2, p. 231-241, 2010.

CHAVES, R. N.; MARTINS, F. S.; SARAIVA, M. V. A.; CELESTINO, J. J. H.; LOPES, C. A. P.; CORREIA, J. C.; VERDE, I. B.; MATOS, M. H.; BÁO, S. N.; NAME, K. P.; CAMPELLO, C. C.; SILVA, J. R.; FIGUEIREDO, J. R. Chilling ovarian fragments during transportation improves viability and growth of goat preantral follicles cultured in vitro. Reproduction, Fertility and Development, East Melbourne, v. 20, n. 5, p. 640-647, 2008. 
CHEN, F.; NAKASHIMA, N.; KIMURA, I.; KIMURA, M. Hypoglycemic activity and mechanisms of extracts from mulberry leaves (Folium mori) and cortex mori radicis in streptozotocin-induced diabetic mice. Yakugaku zasshi: Journal of the Pharmaceutical Society of Japan, Tokyo, v. 115, n. 6, p. 476-482, 1995.

CHENG, M. J.; WU, M. D.; HSIEH, S. Y.; SU, Y. S.; CHEN, I. S.; YUAN, G. F. Secondary metabolites from the endophytic fungus Annulohypoxylon boveri var. microspora BCRC 34012. Chemistry of Natural Compounds, Tashkent, v. 47, n. 4, p. 536-540, 2011.

COSTA, S. H. F.; ANDRADE, E. R.; SILVA, J. R. V.; RODRIGUES, A. P. R.; AMORIM, C. A.; LÔBO, R. N. B.; OHASHI, O. M.; FIGUEIREDO, J. R. Preservation of goat preantral follicles enclosed in ovarian tissue in saline or TCM 199 solutions. Small Ruminant Research, Little Rock, v. 58, n. 2, p. 189-93, 2005.

DALMARCO, J. B.; DALMARCO, E. M.; KOELZER, J.; PIZZOLATTI, M. G.; FRODE, T. S. Isolation and identification of bioactive compounds responsible for the anti-bacterial efficacy of Lotus corniculatus var. São Gabriel. International Journal of Green Pharmacy, Mandsaur, v. 4, n. 2, p. 108, 2010.

DE MELO, G. O.; MALVAR, D. D. C.; VANDERLINDE, F. A.; ROCHA, F. F.; PIRES, P. A.; COSTA, E. A.; DE MATOS, R. G.; KAISER C. R.; COSTA, S. S. Antinociceptive and anti-inflammatory kaempferol glycosides from Sedum dendroideum. Journal of Ethnopharmacology, Limerick, v. 124, n. 2, p. 228-232, 2009.

DE SOUSA, E.; ZANATTA, L.; SEIFRIZ, I.; CRECZYNSKI-PASA, T. B.; PIZZOLATTI, M. G.; SZPOGANICZ, B.; SILVA, F. R. M. B. Hypoglycemic Effect and Antioxidant Potential of Kaempferol-3, 7-O-( $\alpha$ )-dirhamnoside from Bauhinia $\mathrm{f}$ orficata Leaves. Journal of Natural Products, Cincinnati, v. 67, n. 5, p. 829-832, 2004.

ERCISLI, S.; ORHAN, E. Chemical composition of white (Morus alba), red (Morus rubra) and black (Morus nigra) mulberry fruits. Food Chemestry, Barking, v. 103, n. 4, p.1380-1384, 2007.

FLOSS, E. L. Fisiologia das plantas cultivadas: o estudo que está por trás do que se vê. 2. ed. Passo Fundo: UPF, 2004.

GONÇALVES, R. J. S.; CAVALCANTE, A. Y. P.; GOUVEIA, B. B.; LINS, T. L. B.; BARBERINO, R. S.; MENEZES, V. G.; BARROS, V. R. P.; MACEDO, T. J. S.; FIGUEIREDO, J. R.; MATOS, M. H. T. Lower apoptosis rate in ovine preantral follicles from ovaries stored in supplemented preservation media. Zygote, Cambrigde, v. 23, n. 6, p. 1-8, 2015.
GOUVEIA, B. B.; BARROS, V. P.; GONÇALVES, R. J. S.; BARBERINO, R. S.; MENEZES, V. G.; LINS, T. L. B.; MACEDO, T. J. S.; SANTOS, J. M. S.; ROLIM, L. A.; ROLIM NETO, P. J.; ALMEIDA, J. R. G. S.; MATOS, M. H. T. Effect of ovarian tissue transportation in Amburana cearensis extract on the morphology and apoptosis of goat preantral follicles. Animal Reproduction, Belo Horizonte, v. 12, n. 2, p. 316-323, 2015.

GUPTA, R.; SINGH, M.; SHARMA, A. Neuroprotective effect of antioxidants on ischaemia and reperfusioninduced cerebral injury. Pharmacological Research, London, v. 48, n. 2, p. 209-215, 2003.

HIDEAKI, N. A. O. I.; TAKESHIGE, O. T. O. I.; SHIMAMURA, T.; KARJA, N. W. K.; AGUNG, B.; SHIMIZU, R.; MASAYASU, T.; NAGAI, T. Developmental competence of cat oocytes from ovaries stored at various temperature for $24 \mathrm{~h}$. Journal of Reproduction and Development, Tokyo, v. 53, n. 2, p. 271-277, 2007.

JEONG, J. J.; HA, Y. M.; JIN, Y. C.; LEE, E. J.; KIM, J. S.; KIM, H. J.; SEO, H. G.; LEE, J. H.; KANG, S. S.; KIM, Y. S.; CHANG, K. C. Rutin from Lonicera japonica inhibits myocardial ischemia/reperfusion-induced apoptosis in vivo and protects $\mathrm{H} 9 \mathrm{c} 2$ cells against hydrogen peroxidemediated injury via ERK1/2 and PI3K/Akt signals in vitro. Food and Chemical Toxicology, Oxford, v. 47, n. 7, p. 1569-1576, 2009.

KIM, E. S.; PARK, S. J.; LEE, E. J.; KIM, B. K.; HUH, H.; LEE, B. J. Purification and characterization of Moran 20K from Morus alba. Archives of Pharmacal Research, Seoul, v. 22, n. 1, p. 9-12, 1999.

KIM, Y.; NARAYANAN, S.; CHANG, K. O. Inhibition of influenza virus replication by plant-derived isoquercetin. Antiviral Research, Amsterdam, v. 88, n. 2, p. 227-235, 2010.

LINS, T. L. B. G.; CAVALCANTE, A. Y. P.; SANTOS, J. M. S.; MENEZES, V. G.; BARROS, V. R. P.; BARBERINO, R. S.; BEZERRA, M. E. S.; MACEDO, T. J. S.; MATOS, M. H. T. Rutin can replace the use of three other antioxidants in the culture medium, maintaining the viability of sheep isolated secondary follicles. Theriogenology, Stoneham, v. 89, p. 263-270, 2017.

MATA-CAMPUZANO, M.; ÁLVAREZ-RODRÍGUEZ, M.; ALVAREZ, M.; ANEL, L.; PAZ, P. de; GARDE, J. J.; MARTÍNEZ-PASTOR, F. Effect of several antioxidants on thawed ram spermatozoa submitted to $37^{\circ} \mathrm{C}$ up to four hours. Reproduction in Domestic Animals, Berlin, v. 47, n. 6, p. 907-914, 2012. 
MATOS, M. H. T. D.; ANDRADE, E. R.; LUCCI, C. M.; BÁO, S. N.; SILVA, J. R. V.; SANTOS, R. R.; FERREIRA, M. A.; COSTA, S. H.; CELESTINO, J. J.; FIGUEIREDO, J. R. D. Morphological and ultrastructural analysis of sheep primordial follicles preserved in $0.9 \%$ saline solution and TCM 199. Theriogenology, Stoneham, v. 62 , n. 1, p. 65-80, 2004.

MAZIMBA, O.; MAJINDA, R. R.; MOTLHANKA, D. Antioxidant and antibacterial constituents from Morus nigra. African Journal of Pharmacy and Pharmacology, Lagos, v. 5, n. 6, p. 751-754, 2011.

MORETTI, E.; MAZZI, L.; TERZUOLI, G.; BONECHI, C.; IACOPONI, F.; MARTINI, S.; ROSSI, C.; COLLODEL, G. Effect of quercetin, rutin, naringenin and epicatechin on lipid peroxidation induced in human sperm. Reproductive Toxicology, Elmsford, v. 34, n. 4, p. 651-657, 2012.

NOMURA, T. Phenolic compounds of the mulberry tree and related plants. Progress in the Chemistry of Organic Natural Products, Vienna, v. 53, p. 87-201, 1988.

NOMURA, T.; HANO, Y. Isoprenoid-substituted phenolic compounds of moraceous plants. Natural Product Reports, London, v. 11, p. 205-218, 1994.

OLIVEIRA, A. C. B.; OLIVEIRA, A. P.; GUIMARÃES, A. L.; OLIVEIRA, R. A.; SILVA, F. S.; REIS, S. A. G. B.; RIBEIRO, L. A. A.; ALMEIDA, J. R. G. S. Avaliação toxicológica pré-clínica do chá das folhas de Morus nigra L. (Moraceae). Revista Brasileira de Plantas Medicinais, Botucatu, v. 15, n. 2, p. 244-249, 2013.

PEREIRA, D. A.; DALMARCO, J. B.; WISNIEWSKI JUNIOR, A.; SIMIONATTO, E. L.; PIZZOLATTI, M. G.; FRÖDE, T. S. Lotus corniculatus regulates the inflammation induced by bradykinin in a murine model of pleurisy. Journal of Agricultural and Food Chemistry, Washington, v. 59, n. 6, p. 2291-2298, 2011.

QUEIROZ, G. T.; SANTOS, T. R.; MACEDO, R.; PETERS, V. M.; LEITE, M. N.; GUERRA, M. O.; Efficacy of Morus nigra $L$. on reproduction in female wistar rats. Food and Chemical Toxicology, Oxford, v. 50, n. 3, p. 816-822, 2012.

REGASINI, L. O.; VELLOSA, J. C. R.; SILVA, D. H. S.; FURLAN, M.; DE OLIVEIRA, O. M. M.; KHALIL, N. M.; BRUNETTI, I. L.; YOUNG, M. C.; BARREIRO, E. J.; BOLZANI, V. S. Flavonols from Pterogyne nitens and their evaluation as myeloperoxidase inhibitors. Phytochemistry, New York, v. 69, n. 8, p. 1739-1744, 2008.

SANTOS, J. M. S.; MENEZES, V. G.; BARBERINO, R. S.; MACEDO, T. J. S.; LINS, T. L. B.; GOUVEIA, B. B.; BARROS, V. R. P.; SANTOS, L. P.; GONÇALVES, R. J.
S.; MATOS, M. H. T. Immunohistochemical localization of fibroblast growth factor $\square 2$ in the sheep ovary and its effects on pre $\square$ antral follicle apoptosis and development in vitro. Reproduction in Domestic Animals, Berlin, v. 49, n. 3, p. 522-528, 2014.

SANTOS, R. R.; SILVA, J. R.V.; COSTA, S. H. F.; RODRIGUES, A. P. R.; LÔBO, R. N. B.; FIGUEIREDO, J. R. Effect of $0.9 \%$ saline solution and phosphate buffer saline at different temperatures and incubation times on the morphology of goat preantral follicles. Brazilian Journal of Veterinary Research and Animal Science, São Paulo, v. 39, n. 5, p. 254-259, 2002.

SHEN, S. C.; KO, C. H.; TSENG, S. W.; TSAI, S. H.; CHEN, Y. C. Structurally related antitumor effects of flavanones in vitro and in vivo: involvement of caspase 3 activation, $\mathrm{p} 21$ gene expression, and reactive oxygen species production. Toxicology and Applied Pharmacology, New York, v. 197, n. 2, p. 84-95, 2004.

SILVA, I. D. O.; SANTOS, I. C. D.; PETERS, V. M.; FARIA, R. E. D.; ANDRADE, A. T. L. Avaliação do potencial estrogênico de Morus sp. em ratas Wistar: estudo histológico e histomorfométrico: [revisão]. Boletim do Centro de Biologia da Reprodução, Juiz de Fora, v. 22, p. 49-57, 2003.

SILVA, J. R. V.; VAN DEN HURK, R.; COSTA, S. H. F.; ANDRADE, E. R.; NUNES, A. P. A.; FERREIRA, F. V. A.; LOBO, R. N. B.; FIGUEIREDO, J. R. Survival and growth of goat primordial follicles after in vitro culture of ovarian cortical slices in media containing coconut water. Animal Reproduction Science, Amsterdam, v. 81, n. 3, p. 273-286, 2004.

SILVA, J. R. V.; LUCCI, C. M.; CARVALHO, F. C. A.; BÁO, S. N.; COSTA, S. H. F.; SANTOS, R. R.; FIGUEIREDO, J. R. Effect of coconut water and BraunCollins solutions at different temperatures and incubation times on the morphology of goat preantral follicles preserved in situ. Theriogenology, Stoneham v. 54, n. 5, p. 809-822, 2000.

SOUNDARARAJAN, R.; WISHART, A. D.; RUPASINGHE, H. V.; ARCELLANA-PANLILIO, M.; NELSON, C. M.; MAYNE, M.; ROBERTSON, G. S. Quercetin 3-glucoside protects neuroblastoma (SH-SY5Y) cells in vitro against oxidative damage by inducing sterol regulatory element-binding protein-2mediated cholesterol biosynthesis. Journal of Biological Chemistry, Baltimore, v. 283, n. 4, p. 2231-2245, 2008.

SUAREZ, S.; GIL, A.; LORENZO, E. Aloysia citriodora: morphology and density of gladular trichomes, and its relationships with essential oil content. Simpósio Brasileiro de Óleos Essenciais, Campinas, v. 2, p. 78, 2003. 
TAG, H. M. Hepatoprotective effect of mulberry (Morus nigra) leaves extract against methotrexate induced hepatotoxicity in male albino rat. BMC Complementary and Alternative Medicine, London, v. 15, n. 1, p. 252, 2015.

TAMMELA, P.; LAITINEN, L.; GALKIN, A.; WENNBERG, T.; HECZKO, R.; VUORELA, H.; SLOTTE, J. P.; VUORELA, P. Permeability characteristics and membrane affinity of flavonoids and alkyl gallates in Caco-2 cells and in phospholipid vesicles. Archiver of Biochemistry and Biophysics, New York, v. 425, n. 2, p. 193-199, 2004.

TOSHIO, F.; KIYOSHI, K.; SUMIO, T. Antimicrobial activity of 2-arylbenzofurans from Morus species against methicillin-resistant Staphylococcus aureus. Fitoterapia, Milano, v. 76, n. 7, p. 708-711, 2005.

VOLPATO, G. T.; CALDERON, I. D. M. P.; SINZATO, S.; CAMPOS, K. E.; RUDGE, M. V. C.; DAMASCENO, D. C. Effect of Morus nigra aqueous extract treatment on the maternal-fetal outcome, oxidative stress status and lipid profile of streptozotocin-induced diabetic rats. Journal of Ethnopharmacology, Limerick, v. 138, n. 3, p. 691-696, 2011.
WANG, C. P.; LI, J. L.; ZHANG, L. Z.; ZHANG, X. C.; YU, S.; LIANG, X. M.; DING, F.; WANG, $\mathrm{Z}$. W. Isoquercetin protects cortical neurons from oxygen glucose deprivation reperfusion induced injury via suppression of TLR4-NF-кB signal pathway. Neurochemistry International, Oxford, v. 63, n. 8, p. 741749, 2013.

WEI, S. M.; YAN, Z. Z.; ZHOU, J. Protective effect of rutin on testicular ischemia-reperfusion injury. Journal of Pediatric Surgery, New York, v. 46, n. 7, p. 1419-1424, 2011.

ZHANG, R.; YAO, Y.; WANG, Y.; REN, G. Antidiabetic activity of isoquercetin in diabetic KK-A y mice. Nutrition and Metabolism, London, v. 8, n. 1, p. 1-6, 2011. 